\title{
REQUESTIVE UTTERANCES IN SPOKEN JAVANESE OF TEGAL
}

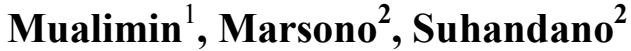 \\ ${ }^{1}$ Doctorate Program of Humanities, Faculty of Cultural Science, Universitas Gadjah Mada, \\ Yogyakarta, Indonesia \\ ${ }^{2}$ Faculty of Cultural Science, Universitas Gadjah Mada, Yogyakarta, Indonesia \\ Email: mualiminischaqfibundip@gmail.com
}

\begin{abstract}
Studying language use as a part of the culture has been carried out for many years in many parts of the world, including in Indonesia. Indonesia which has various cultures has hundreds of local languages in which one of them is Javanese spoken in Tegal. This study is aimed at exploring how the Javanese dialect spoken in Tegal is used in drama radio programs on Pertiwi Radio of Slawi, the capital city of Tegal Regency.The data of the research are in the forms of uttrerances spoken by the characters of the drama containing requestive speech acts using a sociopragmatic approach. The findings of the research show that requestive utterances found in the drama are expressed both directly and indirectly. The direct requestive speech acts are mostly conveyed in utterances with imperative mood, while indirect requestive ones are in the forms of declarative and interrogative utterances. The choice of utterances is influenced by context of social factors where the language is used and is related to request strategy.
\end{abstract}

Key words: Javanese of Tegal dialect; requestive speech acts; request strategy

\section{Introduction}

The Javanese of Tegal dialect or Tegal dialect for short, is spoken by more than 1.500 .000 people (BPS, 2017) or it is about $1,7 \%$ out of the total number of Javanese native speakers numbering 84.000 .000 (Lewis, 2013). It is one of dialects of Javanese which has several characteristics which distinguish it from standard Javanese. Suwadji et al. (1981) mention that one prominent feature is the pronunciation of vowel [a] while in standard Javanese the same sound is pronounced [0]. For example, the words suda'lack', lega 'spacious', ana 'exist' in the Tegal dialect are pronounced as [suda], [loga], and [ana], while in standard Javanese the same words are pronounced as [sudo], [logo], and [ono] respectively. Another peculiarity is that there are voiced consonant sounds at the end of the word. For example, the consonant sound $/ \mathrm{b} /, / \mathrm{g} /$, and /d/ in the word sebab 'cause', bendhug 'drum', and ahad 'sunday' in Tegal dialect are pronounced [sebab], [bədhug], and [ahad], whereas in standard Javanese the same words are pronounced as [səbap], [bədhuk], and [ahat]. In addition to voiced consonant sounds, there are a number of lexicons found in Javanese Tegal dialect which are different from that of standard Javanese. Some examples of lexicons found in Tegal dialect can be seen in Table 1 below.

\begin{tabular}{l|l|l}
\multicolumn{1}{c|}{$\begin{array}{c}\text { Tegal } \\
\text { dialect }\end{array}$} & Javanese & English \\
\hline Priben & Piye & How \\
Anjog & Tekan & Arrive \\
Anta & Cemplang & Tasteless \\
batir & Kanca & Friend \\
ciri & Lepek & saucer
\end{tabular}

Table 1: Lexicon of Tegal dialect Resource: Suwadji et al. (1981)

Javanese language as a product of Javanese culture is also inseparable from Javanese life and culture. The existence of 
speech levels in Javanese reflects how Javanese people interact with others, especially with Javanese.

Research on the Javanese language using the Tegal language as an object of research has not been done much. The research on Tegal language conducted by Suwadji et al. was carried out more than thirty years ago, namely in 1981 . The next study was conducted by Supriatin (2012) and the latest by Mualimin (2018). The last study by Mualimin examined speech acts in Tegal language using some of the data from this study. The research conducted by Suwadji focused on the Tegal language as a dialectological study, namely the Tegal language, which is one of the Javanese dialects. Meanwhile Supriatin's research also tried to see the language of Tegal as a dialect used in Tegal and the surrounding areas, while this study tried to look at the use of Tegal language from a pragmatic perspective, especially speech acts invoked by using the theory of speech acts as proposed by Austin, Searle, and also Trosborg.

Research on the Javanese language using the Tegal language as an object of research has not been done much. The Tegal language research conducted by Suwadji et al. was carried out more than thirty years ago, namely in 1981. The next study was conducted by Supriatin (2012) and the latest by Mualimin (2018). The latest examined speech acts in the Tegal language application some of the data is used in this study. The research conducted by Suwadji focused on the Tegal language as a dialectology study, namely the Tegal language, which is one of the Javanese dialects. Meanwhile Supriatin's research also tried to see the language of Tegal as a dialect used in the Tegal and surrounding areas, while this study looked at the use of Tegal language from a pragmatic perspective, especially speech acts invoked by using the theory of speech acts as proposed by Austin, Searle, and also Trosborg.
In relation to speech acts theory, Austin (1962) states that utterances are not only used to express something but also to do something. Therefore, Austin distinguishes two kinds of utterances which he calls constative speech and performative speech. Searle $(1975,1976)$ developed a speech act theory proposed by his teacher, Austin. According to Searle speech can be categorized into five kinds of speech acts, namely representative (assertive), directive, expressive, commissive, and declaration. Concerning request as a kind of directive speech acts, Searle mentions that requests can be realized directly or indirectly. Direct requests can be conveyed with imperative moods while indirect request can be expressed by either declarative or interrogative moods. In terms of directness, Trosborg (1994) formulates the directness with eight strategies. Those are indirect requests, conventionally indirect covering hearer's ability, willingness, permission, and giving suggestion, conventionally indirect related with speakers' wish, desires or needs, and direct request showing obligation, performative utterances and imperative.

This study will examine how the speakers of Tegal dialect use requestive utterances during informal meeting with their neighbours living in the surrounding housing area with speech acts theories proposed by Austin, Searle, and also Trosborg. However, this research rule will also consider Javanese cultural factors which may influence the choice of utterances proposed by Poedjosoedarmo (2017). Thus, the general formulation of the problem of this research is how the speech acts of requests is realized in Tegal dialect with a pragmatic approach.

\section{Research Method}

This study uses a qualitative descriptive approach, in the sense that this study uses data in the form utterances either words, phrases, clauses or sentences 
and not in the form of numbers. (Sudaryanto, 1993). The primary data of this study are oral utterances containing illocutionary acts of requests used by the speech community in the District and City of Tegal.

Data collection is carried out by observation and interview. Observations were made by looking at the use of request used by Tegal language speakers followed by note-taking techniques, namely by identifying and classifying each utterance which has the illocutionary function of request, both directly and indirectly and of course with regard to the context and situation of speech act. In addition to observations, the researcher also conducts interviews to find out what factors may influence the selection of certain forms.

Data analysis is conducted inductively and is carried out since the researcher discovered the phenomenon of the use of requestive utterances in Javanese of Tegal dialect. The collected data are then analyzed based on the form of the requestive utterances as well as the link between the form of utterances and the factors that can influence the choice of utterance and interpreted to find out the meaning behind the utterance used by the speakers of Tegal dialect.

\section{Finding and Discussion}

Based on theory proposed by Trosborg, the findings of the research show that the requestive speech acts are expressed both directly and indirectly. The direct requestive utterances are realized in three different ways: (1) utterances having illocutionary meaning that the listeners have to do something, (2) utterances containing performative of verbs of request, and (3) utterances in the form of imperative sentences. Meanwhile the indirect requestive utterances are realized in five different ways: (1) declarative sentences without mentioning the performative verbs of requestor the nouns intended by the speakers, (2) interrogative sentences questioning the ability, willingness, or permission of the listeners, (3) utterances having the meaning of giving suggestion to the listeners, (4) utterances containing the wish of the speakers that the listeners do something, and (5) utterances showing desire of the speakers that the listeners do something.

\section{Direct requestive utterances}

In relation to direct requestive speech acts as proposed by Trosborg, the utterances containing direct request can be seen in the data below.

1) Kang Narto, kiye mene, tulung mandheg dhisit.

'Brother Narto, come here, please stop.'

2) Mas supir, mlayune biasa bae. Ora usah ngebut. Kalem bae, kalem.

'Brother driver, Do normal driving. No need of being in a rush. Keep calm.'

3) Pin, kiye nyong digawekna wedang, oh.

'Pin, Give me a drink, please.'

4) Mangane aja karo mlayu, mbokan tiba. 'Don't eat while running, yuo may fall down.'

5) Mas, mampir. Sope esih panas. 'Come around, brother. The soup is still hot.'

6) Sega karo sop, Yu.

'Rice with soup, Sister'

7) Aja kelalen, es teh. 'Don't forget the iced tea.'

8) Dituku rika kabeh bae oh. 'Buy all the thing by yourself, please.'

9) Enyong njaluk sop karo ayam goreng, $\mathrm{Yu}$.

'I ask for soup and fried chicken, Sister.' 
10) Takjaluk kowen demen maring enyong.

'I ask you to love me.

11) Aja ndelengna enyong adus.

'Don't look at me taking a bath.'

12) Nok, kiyeh piringe ditatani.

'Dear (my daughter), the plates are to serve.'

13) Wedange siji maning.

'One more drink.'

In data 1) request is expressed by imperative form indicating by the use of verb mandheg 'stop' preceded by the word tulung 'please' to make the request more polite. Other utterances having imperative can be found in data 5) by the use of the verb mampir 'drop by' . In data 3), 8), and also 12) requests are also expressed directly, but in the form of passive as seen in the use of the verb digawekna ' is made', dituku 'is bought', and ditatani 'is put in order'. The use of imperative sentences with passive forms are quite commonly found in Javanese (Poedjasoedarma, 1979; Mualimin, 2018).

Other direct requests are expressed in the form of prohibition as seen in data 2), 4), 7), and also 11). In data 2) request is indicated by the use of negation ora usah 'don't need to be' and in 4) and 11) by the words aja mlayu 'don't run' and aja ndelengna 'don't look at'. In data 7) request is expressed by the words aja kelalen which means 'don't forget'.

Apart from imperative, passive form and prohibition, direct request speech acts can also be expressed by the use of performative form, either explicitly or implicitly. The explicit performative can be seen from Data 9) and 10) by the use of the word njaluk 'ask' and takjaluk 'I ask'. Whereas in Data 6 and 13 requests are expressed by using implicit performative as indicated by the absence of performative verb njaluk 'ask' as in 9) and 10), but by mentioning the noun sega karo sop 'rice and soup'in 6) and wedang 'drink' in 13). The realization of direct request in Javanese dialect of Tegal can be seen in the diagram 1 below.

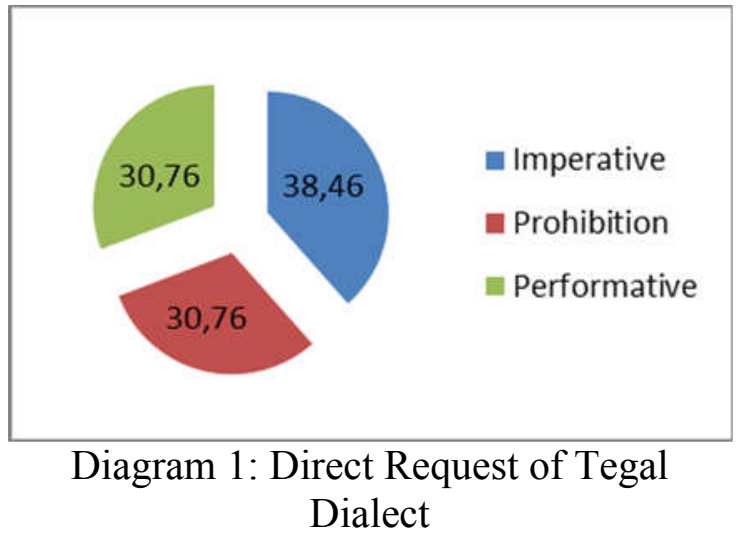

By looking at Diagram 1 above it can be seen that the use of direct request in the form of imperative is more often than the other two, prohibition and performative, where as the use of prohitbition and performative form is the same. Meanwhile the use of indirect request can be found in the next part.

\section{Indirect Requestive Utterances}

Trosborg (1994) mentions that indirect requests can be conveyed by the use of declarative sentence in the form of suggention, and also conveyed by the use of interrogative sentences expressing ability, willingness, and permission. In other words, indirect requestive utterances are realized both in the forms of declarative sentences and interrogative sentences. The indirect requests found in dialect of Tegal can be seen in the following data.

14) Om, Nyong pan setor, mbokan ana kelonggaran.

'My uncle, I'd like to pay the installment, you may have some ease.' 
15) Nyong kepengin diwacakna surat kiye. Nyong matane wis blawur. 'I want you to read this letter for me. My eyes are blurred.

16) Kiye pancen kudu ditekan, endah manjing.

'This surely needs pressure to get in.'

17) Nok, kowen yen milih bojo, kudu dieing-eling pesene bapak ana telu 'Dear, if you have to choose a husband, you should think of your father's three requirements.'

18) Das, kowen duwe andha?

'Das, do you have a ladder?'

19) Kowen bisa jukut dhewek kan? you?'

'You can take (it) yourself, can't

20) Pak, sios mboten toh? Jare arep ngaterke ibu menyang pasar.

'Dear (husband), are we really going? (you said) You were going to accompany me to the market.'

21) Kacang ana?

'Is there any peanut?'

22) Kiye perlu dipel ora ya?

'Does it need mopping?'

23) Nyong lagi butuh dhuwit,pan nggo tuku garem.

'I need some money to buy fertilizer'

24) Kang Narto, sing kudune tanggungjawab kiye sampeyan.

'Brother Narto, you must be responsible.'

Data 14) shows the requestive utterance is expressed indirectly bu the use of declarative sentence without mentoning either the action and also the the thing needed. The speaker wants the listener to pay back the loan but the speaker doesn't mention either the verb of paying back the money or the sum money.

Data 15) shows that the request is expressed indirectly with declarative sentence contaning desire of the the speaker indicated by the use of the word kepengin 'want'. The utterance means that the speaker asks the listener to read the letter for the speaker.

Data 16), 17), 22), 23), and 24) show that the requests are expressed indirectly by the use of utterances showing the speaker's wish. In 16), 17), and 24) requests are indicated by the word $k u d u$ 'must', in 22) and 23) requests are expressed indirectly by the use of the word perlu 'need' in 22) and butuh 'need' in 23). The use of indirect request in Javanese of Tegal dialect can be seen in Diagram 2.

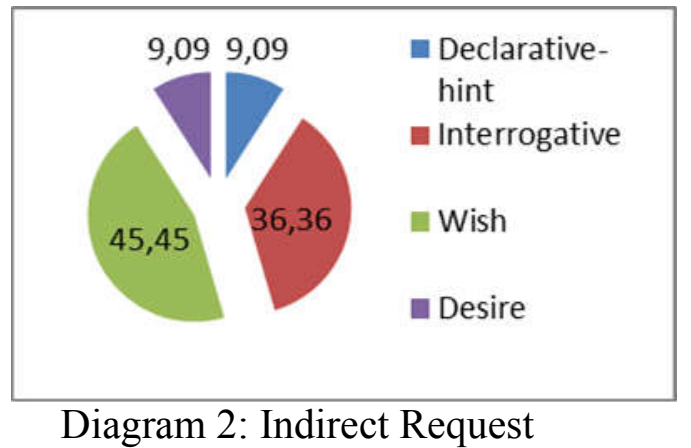

From the diagram above the use of Wish is the most among the others, and the use of Interrogative for request is also quite often, meanwhile the use of declarative showing hint and desire is the same.

Based on the explanation above, the distribution of requestive utterances found in the data can be seen from table 2 . 
e-ISSN 1412-9418

Humanika Vol.26. No.12019 Copyright @2019

Tersedia online di http://ejournal.undip.ac.id/index.php/humanika

Requestive Utterance

\begin{tabular}{c|c|c|c|c|c|c}
\hline \multicolumn{3}{c|}{ Direct } & \multicolumn{4}{c}{ Indirect } \\
\hline Imperative & Prohibition & Performative & Declarative & Interrogative & Wish & Desire \\
\hline 5 & 4 & 4 & 1 & 4 & 5 & 1 \\
\hline $21 \%$ & $17 \%$ & $17 \%$ & $4 \%$ & $17 \%$ & $21 \%$ & $4 \%$ \\
\hline \multicolumn{3}{c|}{$13(55 \%)$} & & \multicolumn{5}{c}{$11(45 \%)$}
\end{tabular}

Table 2: The distribution of requestive utterance Resource: Mualimin, 2018

Table 2 above shows that requestive utterances in Javanese of Tegal tend tobe expressed directly rather than indirectly. The direct requests are in the forms of imperative sentences, performatives and passive, while the indirect ones are mostly expressed in interrogative, and then declarative, and unlikely in conditional sentences. This finding is in agreement with Hashemian's finding (2014) and also Fukushima (2003) saying that Iranian speakers learning English also tend to use more direct utterances than Canadians using English as their native language. This findings may also reflect the attitude of most people living in Tegal that in giving requests they prefer to use bald on record strategy than other strategies (Mualimin, 2018, personal interview with Hadi conducted in March 2018). Hadi was one of the informants involved in this research who has actively involved in writing a dictionary on Tegal dialect.

\section{Factors influencing the Choice of requestive Utterances}

Apart from the forms of requestive utterances, the next discussion will be on the factors that may influence the choice of requestive utterances. To deal with them, here are some data related to the matter.

23a) Kang Narto, kiye mene, tulung mandheg dhisit.

'Brother Narto, come here, please stop.' 23b) Sabar, sabar, Kang

Context: Two people of the same age who are also friends talking about something.

In the above situation, the first person uses an utterances of request in imperative form. This is indicated by the use of verb mandheg in the utterance "Kang Narto, kiye mene, tulung mandheg dhisit. The use of imperative form in the utterance is due to the fact that both the speaker and listener are close friends of the same age. The choice of utterance will be different when they are not close friend or when they are strangers. In other words the factor influencing the utterance is the close relationship beween them.

24a) Niki kula pengin ngerti, ... keadaane sawahe Kirman kados ngeten. 'I would like to know, ... the condition of Kirman's rice field is like this.

24b) Enggih, enggih. 'Yes, yes.'

Context: Two people of different social level talking about a rice field condition

In the above conversation, the speaker wants the listener to explain why the matter happens. Instead of using imperative form, the speaker uses utterances in the form of declarative mood. The use of declarative means that the speaker uses indirect requestive utterance. This is due to the fact that they are not 
close friends indicated by the use of indirect request and also krama speech level instead of ngoko one. This phenomenon indicates that so far Javanese people tend to use krama when they talk to persons they do not know well as mentioned by Poedjosoedarmo (1979, 2017) and also Ekowardono (1993).

\section{Conclusion}

From the expalantion above, it can be concluded that the speakers of Tegal dialect, when they communicate, use both direct and indirect form of requestive utterance. The direct requestive utterances are expressed in imperative utterance, performative utterance, or passive form. The direct requestive forms are used when the speaker and the listener know each other or they are close friends.

The indirect requests are used in the form of declarative or interrogative sentences. The use of declarative or interrogative sentences to request something is a marker that the requests are expressed indirectly. The use of indirect requestive utterance may be inflenced by the relationship among the participants who do not know each other well.

\section{Acknowledgement}

This paper is a part of research funded by DP2M, the Ministry of Education and Culture, BOPTN, Fiscal year 2014 with DIPA of Diponegoro University, numbered DIPA: 023.04.2.189185/2014. This paper is also a part of my dissertation at Gadjah Mada University, Yogyakarta, Indonesia

\section{References}

Austin, J.L. (1962). How to Do Things with Words. New York: Oxford University Press.

BPS Kabupaten Tegal. (2017). Data Penduduk Kabupaten Tegal Tahun
2017. Diunduh dari laman http://tegalkab.bps.go.id pada tanggal 26 Januari 2018.

BPS Kota Tegal. (2017). Data Penduduk Kota Tegal Tahun 2017. Diunduh dari laman http://tegalkota.bps.go.id pada tanggal 26 Januari 2018.

Ekowardono, B. Karno dkk. (1993). Kaidah Penggunaan Ragam Krama Bahasa Jawa. Jakarta: Pusat Pembinaan dan Pengembangan Bahasa

Fukushima, Saeko. (2003). Request and Culture: Politeness in British English and Japanese. Bern: Peter Lang.

Hashemian, M. (2014). "A Pragmatic Study of Requestive Speech Acts by Iranian EFL Leaners and Canadian Native Speakers in Hotels".The Journal of Teaching Language Skills 6 (2)

Lewis, M. Paul, Gary F. Simons, and Charles D. Fennig. (2013). Ethnologue: Languages of the World, seventeenth edition. Dallas, Texas: SIL International. Online version: http://www.ethnologue.com

Mualimin. (2018). “Tindak Tutur Permohonan dalam Bahasa Jawa Dialect Tegal". Unpublished Dissertation. Universitas Gadjah Mada, Yogyakarta.

Poedjasoedarmo, Soepomo et al. (1979). Tingkat Tutur Bahasa Jawa. Jakarta : Pusat Pembinaan dan Pengembangan Bahasa. Depdikbud.

Poedjosoedarmo, Soepomo.(2017). "Language Propriety in Javanese" Journal of Language and Literature, Vol. 17 No. 1

Searle, J.R. (1975). "Indirect Speech Arts" dalam P. Cole \& J. Morgan (eds.). 
Syntax and Semantics. Vol.3:Speech Acts. New York: Academic Press, 5982.

Searle, J.R. (1976). "The classification of illocutionary acts". Language in Society $5,1-24$.

Sudaryanto. (1993). Metode Dan Aneka Teknik Analisa Bahasa. Yogyakarta : Duta Wacana University Press.

Poedjosoedarma, Soepomo dkk. (1979). Tingkat Tutur Bahasa Jawa. Jakarta: Pusat Pembinaan dan Pengembangan Bahasa
Supriatin, Abadi. (2012). "Penggunaan Bahasa Jawa Dialek Tegal" in Proceeding International on Language Maitenance and Shift II, 5-6 July pp. 364-368

Suwadji dkk. (1981). Dialek Bahasa Jawa di Pesisir Utara Jawa Tengah (Tegal dan Sekitarnya) Jakarta: Depdikbud

Trosborg, Anna. (1994). Interlanguage Pragmatics: Request, Complaints, and Apologies. New York: Mouton de Gruyter. 